\title{
REFLEXÕES CRÍTICAS SOBRE O INSTITUTO DO CONCUBINATO NO DIREITO BRASILEIRO
}

\section{Roberta Drehmer de Miranda ${ }^{1}$}

\section{RESUMO}

O presente trabalho tem por finalidade demonstrar a ausência, no direito brasileiro, de uma clara distinção entre o concubinato, a união estável e o casamento. Embora tenha havido significativa evolução doutrinária e jurisprudencial sobre os institutos, culminando com o advento do Código Civil de 2002, que sobrepõe o instituto do casamento sobre o concubinato e a união estável, ainda podem ser vistos julgados, principalmente no Tribunal de Justiça do Rio Grande do Sul, que dão aos concubinos status de casados, concedendo efeitos patrimoniais próprios do direito de família, manifestamente ilegais e antijurídicos. Por meio de uma análise históricosociológica, o presente artigo elucida que somente o casamento constitui família, sendo a união estável apenas considerada pelo Direito como

1 Bacharel em Ciências Jurídicas e Sociais pela Universidade Federal do Rio Grande do Sul (UFRGS). Mestre em Direito Público pela Universidade Federal do Rio Grande do Sul (UFRGS). Doutoranda em Sociologia do Direito pela Universidade Federal do Rio Grande do Sul (UFRGS). Professora de Direito de Família da Faculdade Dom Bosco de Porto Alegre. Advogada. Membro do Instituto dos Advogados do Rio Grande do Sul (IARGS). Bolsista da CAPES. Currículo: http://buscatextual.cnpq.br/buscatextual/ visualizacv.jsp?id=K4705763A8.

Endereço eletrônico: roberta_drehmer@yahoo.com. 
equiparada ao matrimônio e, por fim, o concubinato, como situação fática antijurídica, não aceita pelo Direito, resultando tão somente em efeitos patrimoniais cíveis, como sociedade de fato.

Descritores: Concubinato. União estável. Relações interpessoais. Direito de família: Brasil.

\section{ABSTRACT}

This workproposes to demonstrade the absent, in the brasilian law, of a clear distinction between commonlaw marriage, "união estável” and marriage. Though has been an significative evolution of the doctrine and the jurisprudence about the subject, wich culminate in the begining of the 2002 Brazilian Civil Code that overrides the marriage above common-law marriage and the "stable union", still we can see precedents, specially in the Rio Grande do Sul Court, that gives to the concubines an couple status, like marriage, and a series of family law patrimonial efects, wich are clearly ilegal and against the law. Through an historical and sociological analisis, the presente article elucidates that only marriage can make a family, and the "stable union" is only considerades by the law as treated like a marriage, and, at last, the common-law marriage, as a fatical situation against the law, and not acepted by the law, wich results only in patrimonial efects, as a common-law society.

Descrptors: Common law marriage. "Stable union". Interpersonal relations. Family law: Brazil.

\section{INTRODUÇÃO}

As relações humanas, no decorrer da história, sempre nos trazem surpresas e mistérios. Muito mais quando faz relação com a origem e evolução da família, ponto de partida de toda civilização política e do próprio direito, na medida em que foi no seio das relações familiares que as primeiras convenções positivas tornaram-se gerais e aplicáveis a todos, no âmbito social.

O surgimento da família está intimamente ligado à religião. A preocupação com a descendência e com a existência de uma prole definida fez com que os povos primitivos - mormente os que viveram transitoriamente uniões livres - procurassem estabelecer relações monogâmicas fixas, celebradas com ritos religiosos, que tivessem uma exterioridade duradoura e constante. Essa, portanto, é a origem da família fundada sob o casamento.

Em paralelo a essas uniões duradouras constituídas por um ca- 
samento, algumas uniões, que poderíamos cunhar "extraconjugais" (que não eram, repita-se, o caso central, pois não tinham respaldo algum na religião doméstica), não tinham reconhecimento moral nem sociopolítico. A concubina era subordinada ao chefe de família, mormente para manter somente relações sexuais, e não participava socialmente nem patrimonialmente do status do chefe, em igualdade com a esposa. A concubina permanecia nessa situação e assim aceitava, por circunstância cultural.

Portanto, as situações sociais, do ponto de vista jurídico, sempre foram muito claras. Havia a separação nítida entre a esposa e a concubina. Por isso ser entendível que a maioria das legislações então vigentes assim disciplinasse as relações familiares fundadas no casamento e as extraconjugais, nessa se enquadrando a concubinária (livre ou impura).

Contudo, podemos dizer que as ideias renascentistas, liberais, modernas, são, em verdade, o fundamento dos movimentos contemporâneos de liberdade moral e sexual da contemporaneidade (a partir dos anos 60 e 70), foi então que o padrão histórico-jurídico da família fundada sob o casamento passou a ser questionado. Em primeiro lugar, pela posição tomada pela Igreja Católica no sentido de considerar como família verdadeira aquela fundada sob o casamento em seu sentido sacramental, inadmitindo, pois, a separação judicial e o divórcio. Levando em conta que há um grande número de casais autointitulados "católicos" que estavam, em verdade, buscando o divórcio por falência da relação pessoal conjugal (e, portanto, forçavam um aval da Igreja) ou que se casaram por conveniência (e, portanto, não viam mais razão de viverem sob o mesmo teto), obviamente a posição católica foi a primeira a ser combatida e, do ponto de vista do direito positivo, foi derrotada, pois hoje a maioria das legislações estatais admite o divórcio. Em segundo lugar, as uniões livres, que assim o eram, pois havia alguma circunstância social ou legal que impedia tal relação, passaram a ser a primeira opção, já que numa sociedade de individualismo extremado e de livre concorrência a desconfiança acaba por imperar em todas as relações pessoais.

Dessa forma, houve uma gradativa alteração do próprio termo "concubinato", que era antes considerado como união livre (lícita ou ilícita) não jurídica, passa a ter relevância jurídica sob dois aspectos: quando existente entre duas pessoas, livres, desimpedidas, com relação constante e duradoura (então chamada "união estável”, união de fato que não necessita de alguma celebração especial ou rito de comunhão esponsal); e quando existente entre duas pessoas, sendo uma delas com algum impedimento decorrente de 
obrigação ou convenção esponsal. A primeira tem abrigo sob o direito; a segunda (o antigo concubinato impuro), o tem apenas sob o ponto de vista patrimonial, como se fosse constituída uma sociedade de fato.

O presente ensaio tem por objeto trabalhar as seguintes questões: quais os efeitos do concubinato, se existente? Ou: é lícito ou em conformidade ao direito (tomado aqui também como tradição) considerar o concubinato como família? Ainda: qual o limite entre o concubinato e a união estável, e se há possibilidade de transformação do primeiro no segundo? Tais questionamentos são candentes na prática jurídica, e são vistos na jurisprudência com frequência, sendo missão do jurista delimitar devidamente os institutos, sob o ponto de vista da tradição jurídica e da lei positiva, a fim de que nem um nem outro seja esquecido ou subjugado a terceiro plano, o que levaria, sem dúvida nenhuma, a um subjetivismo ou decisionismo, bem como a um relativismo extremo do próprio direito.

O trabalho está dividido em duas partes. Na primeira, abordar-se-ão algumas noções fundamentais acerca do concubinato, seu conceito, origens, e o tratamento legal disciplinado pelo sistema positivo brasileiro, mormente pelos Códigos Civis de 1916 e o atual, de 2002. Na segunda parte, analisarse-ão alguns elementos dogmáticos e práticos da relação concubinária, a evolução normativa e jurisprudencial, buscando fixar, em conformidade com a tradição jurídica, o correto espaço e tratamento desse instituto no direito civil e familiar.

\section{Noções fundamentais acerca da relação concubinária}

Abordam-se: a relação concubinária (conceito, origens, noções fundamentais) e o concubinato nos Códigos Civis brasileiros de 1916 e 2002.

\subsection{Conceito e origens da relação concubinária}

Do ponto de vista etmológico, "concubinato" vem de concubans, concubantis, significando "o que dorme ou se deita com” (Rizzardo, 1985, p. 218). Exprime, pois, a ideia de comunidade de leito. Num sentido comum, é a união entre um homem e uma mulher sem os vínculos do matrimônio.

Essa união pode se manifestar de duas formas. Num sentido mais amplo, é a união transitória entre um homem e uma mulher, num mesmo teto ou em tetos diferentes, visando manter relações sexuais e afetivas com o parceiro, sem o vínculo do matrimônio - sendo estado intermediário entre a relação fugaz e o casamento.

Num sentido estrito, é a união permanente entre um homem e 
uma mulher, com características semelhantes à convivência more uxório do casamento, só que sem o vínculo formal deste. É uma união de fato que não visa tão somente à relação afetiva, mas uma comunhão de vida a prolongar-se no tempo.

Obviamente, o segundo sentido enquadra-se ao que hoje se chama “união estável”, considerada pelo direito como entidade equiparada à família formada pelo casamento (Reale, 2004), exatamente por ter características e finalidade semelhantes ao deste último.

Essa definição de concubinato pôde ser vista mais nitidamente, na história do direito, com os romanos, que baseavam fundamentalmente a família sob o casamento, pois havia a preocupação de transmissão, à prole e aos demais membros da família, o encargo do culto religioso e da administração do patrimônio. ${ }^{2}$ Não havia família sem casamento; as uniões livres não eram ilícitas (sob o ponto de vista criminal, inclusive), desde que constituídas por pessoas livres que não estivessem em situação contrária ao direito (como o adultério) ou pelo pater que quisesse manter sob sua égide mulher para manutenção de relações transitórias (tanto no casamento cum manu como sine manu).
Beviláqua faz rico comentário sobre a relação entre os esponsais e os concubinos (1905, p. 219). Nos povos antigos a mulher sempre fora considerada inferior moralmente e incapaz juridicamente; tinha total dependência para com o marido, e, na sua morte, para com os filhos ou outros parentes designados para sustentá-la. Não tinha patrimônio próprio e apenas administrava poucas atividades do lar, do cuidado e da educação dos filhos. O marido tinha o dever de sustento, de afeto e, em alguns povos, até de fidelidade; mas também tinha o direito de punir, sendo comum o homicídio em casos de adultério (gérmen talvez da legítima defesa da honra).

Contudo, o direito hebraico já concedia as raízes do tratamento entre esponsais do Ocidente, posto que a mulher tem papel relevante e fundamental na família judaica. O marido cerca a mulher de intensa consideração; tem o direito de cominar penas a quem a ofender fisicamente, a quem seduz uma virgem, a quem maldiz sua mãe. Há reciprocidade de deveres entre o marido e a mulher, esta tendo inclusive direito à participação nos ritos familiares religiosos (ainda que em público deva comparecer à sinagoga em separado). Ainda que não exista uma igualdade plena, há,

2 No mesmo sentido, comentando a formação da família a partir da religião, pela celebração do casamento, o estudo de Fustel Coulanges (1998, p. 37- 52). 
evidentemente, uma evolução no relacionamento intrínseco entre os esponsais, sendo alguns os casos de concubinatos ou relacionamentos passageiros (na Bíblia, é conhecido o exemplo de Salomão, mas pouco falado o caso de Moisés).

Em Roma, as formas conjugais jurídicas do período pré-clássico (confarreatio, coemptio, usus) atribuem ao marido uma autoridade máxima (manus) sobre a mulher, considerada como filha do pater, ou marido, sem direito a patrimônio, aquisição ou venda de bens próprios. Era a regra.

Com a introdução, no período clássico, do casamento livre (sine manu), ainda que mantido o direito de julgar a esposa (inclusive cominando com a morte) em situações consideradas graves como o adultério, homicídio, magia ou embriaguez, o patrimônio da mulher permanecia dela, bem como sua submissão, em termos de autoridade, ao pater precedente ou primeiro; o casamento, então, era constituído sob o regime dotal; a mulher passou a ter uma individualidade maior na família, inclusive na educação dos filhos; passou a ser partícipe nos ritos religiosos familiares; participa das honras e do status social do marido. Todas as características que não eram vividas ou estendidas à concubina, considerada, faticamente, como uma serva ou escrava do pater.
Do ponto de vista do cidadão romano, todos buscavam a constituição de família pelo matrimônio; alguns mantinham como concubinas normalmente servas ou escravas e mulheres cidadãs romanas, apenas com fins de relações sexuais. A escolha pelo concubinato trazia problemas com relação à filiação, já que essa dependia do consentimento do pater se extraconjugal. Para evitar problemas com a filiação, a partir do Imperador Constantino, o direito procurava incentivar a transformação do concubinato em casamento, não sendo apenas uma questão de formalidade, mas sim de constituição mesma da família, sob o aspecto dos direitos e das obrigações.

Foi com Justiniano que o concubinato (como união livre de fato, e não entre um homem ou mulher casado e outro ou outra livre) alcançou status jurídico, sendo reconhecido como união lícita, contudo, sem o vínculo da affectio maritalis e honor matrimonii, próprios do casamento (Petit, 1970).

No direito canônico, o concubinato é definido como a relação entre o homem e a mulher com vistas à constituição de relações sexuais sem o propósito de formação de uma comunidade fundada na mútua respeitabilidade exigida pelo sacramento. Não é negada a característica de estabilidade e constância, tampouco a finalidade de vida em comum; o que acentua a Igreja é a ausência do compromisso 
marital exigido pelo sacramento e dos requisitos intrínsecos que dele advém, como a castidade no período do namoro e do noivado.

Como o critério, in casu, é religioso (e objetivo), deve-se entender a prescrição canônica sob o ponto de vista do pecado (infidelidade de um com o outro) e da elevação do casamento à categoria de sacramento (instituído por Deus, mediante Cristo, e dado pelos esponsais, perante a autoridade eclesiástica ou outra devidamente autorizada para tanto, como o diácono, que não é sacerdote). ${ }^{3}$

A prescrição canônica influenciou o direito positivo ocidental após a queda de Roma sob o ponto de vista dos requisitos para constituição da família pelo casamento. A colocação da relação concubinária como não familiar lícita, se união livre, e como ilícita, se algum dos concubinos for impedido, encontra origens na regra canônica da fidelidade e compromisso público e formal dos esponsais. De onde a ideia de consideração da união livre como sociedade de fato (já que é lícita, mas não é família) que, portanto, traz efeitos civis patrimoniais próprios desse instituto, além da famosa “indenização por serviços prestados”.

Aos poucos, alguns efeitos sucessórios foram dados, culminando com a modificação do instituto para a “união estável”, então considerada como entidade familiar equiparada à família constituída pelo casamento.

\subsection{O Concubinato sob a Égide dos Códigos Civis Brasileiros de 1916 e 2002}

Segundo Alvaro Villaça Azevedo, o conceito de concubinato leva em consideração a existência de duas espécies dessa relação: o puro e o impuro (Azevedo, 1987, p. 24). O primeiro é, efetivamente, aquela relação estável e duradoura, em que há comunhão de vida e finalidade de constituição de família, sem o vínculo do casamento (hoje caracterizada como união estável). Portanto, tratase de união entre solteiros, viúvos, separados judicialmente e não impedidos de nenhuma forma pelo casamento ou outra relação (mesmo concubinária, também).

O segundo - impuro - advém de relação ilícita (prescrita em lei, normalmente), mormente externada pelo adultério, incestuoso ou desleal (relativamente a outra união de fato), como de um homem ou mulher casado ou concubinado, que mantenha, paralelamente ao seu lar, outro de fato. Para Alvaro Villaça Azevedo,

3 Sobre o direito canônico e suas correspondentes regras sobre a família e o casamento, cabe ver a lição de Carlos Silveira Noronha (1999, p. 58-62). 
desse tipo de relação não pode advir nenhum efeito jurídico sequer, a não ser nos casos de concubinos de boa-fé, situação, portanto, análoga ao casamento "putativo” (Azevedo, 1987, p. 66).

Dessa forma, a fim de precisar a terminologia jurídica, procurou-se no direito atrelar o termo "concubinato" apenas às relações ilícitas (impuro) e àquelas passageiras ou transitórias sem vínculo marital ou com características de união duradoura com comunhão de vida, a fim de esclarecer a limitação de efeitos patrimoniais e pretensamente familiares de tais relacionamentos.

Auniãolivre, constante, duradoura, com finalidade de comunhão de vida, passou a ser cunhada "união estável” e a então concubina, o termo “companheira” - cujo sentido é elevar a posição da mulher que permanece muito tempo em estado marital com o homem, diferenciando-a daquela que permanece em estado de transitoriedade sem manter características semelhantes ao casamento.

O precedente jurisprudencial (leading case) que definiu a questão foi o RE 83.930, no qual o Supremo Tribunal, reiterando duas decisões anteriores no mesmo sentido, consolidou a orientação de distinguir juridicamente "concubina” de "companheira”, esta sendo aquela que vive em convivência more uxório com o homem separado judicialmente ou de fato, enquanto que aquela seria a mu- lher com quem o cônjuge adúltero tem encontros periódicos fora do lar, ainda que garanta um mínimo de sustento a ela (Rizzardo, 1985, p. 164).

A legislação pátria tem tradição de separar o concubinato do casamento, tendendo a não conceder efeitos jurídicos àquele, nas duas modalidades. A evolução jurisprudencial, acompanhando a própria transformação social, foi modificando o status do concubinato puro, até culminar na legislação específica que disciplina a posição jurídica da companheira (Lei da União Estável), e, por fim, no Código Civil de 2002 (Brasil, 2003).

Seguindo o histórico esboçado por Alvaro Villaça Azevedo, observamos que as Ordenações Filipinas apenas disciplinavam a união conjugal pelo casamento, prevendo, inclusive, a possibilidade de reivindicação, pela esposa, de bens que seu marido tivesse doado à sua concubina, ou qualquer mulher que, esporadicamente, manteve relações sexuais (Azevedo, 1987, p. 68). Os tribunais, nos casos de concubinato puro, chegavam a presumir o casamento entre eles para, assim, dar-lhes efeitos jurídicos.

Essa prescrição foi reproduzida na Consolidação das Leis Civis de Teixeira de Freitas, que previa, em seu art. 147: a reinvindicação de bens pela mulher casada doados à concubina; anulação das doações pela esposa e também por seus descendentes ou herdeiros necessários; a mulher, mesmo 
separada, poderá anular doações ou vendas fictícias feitas pelo ex-marido à concubina (Azevedo, 1987, p. 68).

Com relação aos filhos, esses eram considerados naturais quando não houvesse entre os pais impedimento para casar. No tocante à herança, se filhos forem extraconjugais de não nobres (peões), todos sucederão igualmente; se filhos de nobres, apenas sucedem os "legítimos". Assim, a legitimidade condizia muito mais para fins de herança do que por filiação por si só, já que inclusive aí os filhos eram considerados naturais, mesmo que por relação ilícita (os chamados "filhos espúrios”, fruto de adultério, incesto e sacrilégio), aos quais era garantido o direito a alimentos e à própria investigação de paternidade. A vedação sucessória legítima era expressa, salvo a testamentária, em que os filhos espúrios poderiam ser instituídos herdeiros (Rizzardo, 1985, p. 185).

O Código Civil de 1916 não regulamentou o concubinato, mas também não o proibiu (Brasil, 2003). O caso exemplar era o casamento e, portanto, a regulação era toda dirigida a ele.

Com o acréscimo do adjetivo “comuns", a possibilidade de reinvindicação de bens pela esposa permaneceu denotando que ela não podia interferir em doações de bens próprios feitas pelo marido à concubina (Azevedo, 1987, p. 78). Outros efeitos civis permanecerem os mesmos, apenas com uma carga maior ao concubinato adúltero, que parece ser a situação ventilada na maioria dos dispositivos do Código de 1916 (Brasil, 2003).

Algumas modificações passaram a ser consideradas, diante da evolução social, pela legislação posterior esparsa. Um dos casos é a lei de acidentes do trabalho (Decreto-Lei 7036, de 44), que estabeleceu que a companheira mantida pela vítima tem os mesmos direitos do cônjuge legítimo, caso esse não exista ou não tenha direito ao benefício, desde que tenha sido mencionada como beneficiária em ato solene (carteira profissional ou livro de registro de empregados); posteriormente, foi previsto o direito ao seguro à companheira, indicada pelo companheiro. Mais tarde, a legislação previdenciária passou a garantir os direitos de pensão por morte à companheira, bem como sua inserção como dependente do companheiro (Azevedo, 1987, p. 79).

Com a inserção do divórcio pela Lei 6515/77, o concubinato puro passa a ser considerado de forma mais relevante pela ordem jurídica (inclusive para fins de reconhecimento pleno de filhos) (Brasil, 2003). Já não se tinham mais dúvidas acerca da ilicitude do concubinato impuro; mas a discussão residia nas formas como o direito poderia recepcionar essa outra espécie de concubinato que passou a ser vivida por uma expressiva quantidade de casais. 
Na jurisprudência pátria já se reconhecia os efeitos jurídicos do concubinato puro, como já fora explanado, instituindo a diferenciação entre companheira e concubina, o que de fato foi reconhecido pelas Leis 8971/94 e 9278/96. Mas foi com a Constituição de 1988 que dita união foi reconhecida como entidade familiar, à luz do caput do art.226, que dispõe acerca da família como célula nuclear da sociedade (Brasil, 2003).

O Código Civil de 2002, nessa mesma linha, consagrou como família nuclear aquela formada pelo casamento, já que nela há, pela escolha feita entre os esponsais, a presunção da finalidade da comunhão plena de vida e da constituição de núcleo familiar, pelos filhos. Equiparado ao casamento, o Código regulou a união estável (o então concubinato puro) em seu art.1723, considerando-a como entidade familiar e outorgando-a as mesmas prerrogativas e deveres dos casados. Definitivamente, o Código consagrou a diferença entre concubinato adulterino (impuro) e união estável (concubinato puro) (Brasil, 2003).

\section{ASPECTOS DOGMÁTICOS E PRÁTICOS DA RELAÇÃO CONCUBINÁRIA}

Abordam-se: os efeitos do concubinato no direito pátrio atual, tanto civis quanto patrimoniais, e a posição do concubinato entre as entidades familiares.

\subsection{Efeitos Civis e Patrimoniais do Concubinato no Direito Pátrio Atual}

O artigo 1.727 do Código definiu o concubinato como "as relações não eventuais entre homem e mulher, impedidos de casar [...]" (Brasil, 2003). A partir da conceituação de cada um dos institutos, percebe-se que o que separa a união estável do concubinato é a conversibilidade ou não da relação em casamento.

Ora, o Código vigente manteve o direcionamento definido no Estatuto Civil anterior, no sentido de reservar ao concubinato o tratamento de sociedade de fato sem o intuito de constituir família, tendo em vista que surgiu em meio a ato ilícito grave, que é o adultério. Diante disso, a impossibilidade de conversão em casamento ou de reconhecimento de status de companheira à concubina - já que verificáveis, na situação concreta, os impedimentos para constituição do casamento e da união estável, previstos no Código - leva ao reconhecimento jurídico de efeitos civis patrimoniais obrigacionais, bem como dos elementos constitutivos então dispostos pela teoria geral comercial, um deles, o esforço comum na formação do patrimônio (Brasil, 2003). 
Rizzardo nomina alguns elementos de identificação da sociedade de fato definida pelo concubinato: a affectio societatis (o ânimo ou intenção de associar-se); a posse do estado de casado (a); a conjugação de esforços e interesses; a notoriedade do relacionamento; a conduta dos concubinos; o dever de fidelidade; a habitação comum; a convivência more uxório; a continuidade da união; a unidade do casal; a dependência recíproca dos concubinos (Rizzardo, 1985, 171-179). Por óbvio que alguns aspectos elegidos (mormente a conjugação e comunhão de vida, a notoriedade, unidade e constância da união, e a convivência more uxório) são típicos do concubinato puro, hoje tratado como união estável, tendo, portanto, efeitos civis próprios do direito de família, e não do direito das obrigações (inclusive, sem necessidade de prova do esforço comum).

A affectio societatis é elemento basilar definidor do concubinato (Rizzardo, 1985, p. 171). Mesmo sendo a relação amorosa fruto de infidelidade e adultério de um dos concubinos (ou de ambos), não há que se negar a intenção de permanência de uma sociedade, com interesses e finalidades comuns, pois, se fosse o contrário, a união seria considerada como "livre" ou passageira, sequer podendo ter algum tipo de reconhecimento jurídico válido. O concubinato que enseja efeitos civis obrigacionais é o que se mantém no tempo, apesar dos impedimentos legais existentes na relação; e se há formação mínima de patrimônio, esse se divide em conformidade com a contribuição de cada um, ou, na ausência de estipulação ou em dificuldade probatória, o critério geral de metade para cada parceiro.

No que se refere à posse do estado de casado, talvez seja o elemento que traz maiores discussões e dúvidas, normalmente resolvidos em consonância com o caso concreto e no conjunto probatório. Em tese, o concubinato não admite a posse do estado de casado, pois há na relação um ilícito civil, como já se disse; contudo, situações em que o concubino(a) encontra-se em processo de separação de fato, ou que permanece no estado de boa-fé (sem ter o devido conhecimento dos impedimentos do outro), o status de casado pode ser reconhecido e, assim, os efeitos serão disciplinados pelo direito de família, resguardando, por óbvio, os interesses e direitos da família legítima (formada pelo casamento ou união estável).

Mesmo essa orientação - hoje admitida por boa parte da jurisprudência pátria - guarda contrariedades jurídicas. Ainda que o concubino(a) esteja de boa-fé, a divisão patrimonial em conformidade com o direito de família traz dificuldades intransponíveis, como na aplicação de regime de bens ou, inclusive, 
em caráter sucessório. Ter-se-á, inevitavelmente, uma dupla partilha (aplicável à família anterior, formada pelo casamento ou união estável, e ao concubinato posterior), sem contar a indefinição acerca de qual regime de bens será aplicável ao concubinato, pois não há previsão legal ou sequer contrato privado entre os concubinos que assim o estipule (por óbvio, pois, se existiria, em conformidade com a lei civil, seria um contrato típico de união estável).

No caso da sucessão, igualmente não encontraria guarida a orientação de aplicar-se ao concubinato regras de direito de família, pois o direito sucessório segue regras positivas próprias e peculiares, as quais não admitem, por exemplo, o reconhecimento de outros herdeiros necessários, nem da concubina(o) como herdeira testamentária, consoante o Código Civil Brasileiro (Brasil, 2003).

Por isso, a posição mais razoável - que não fere a lei, nem o costume jurídico, e nem a situação ventilada no caso concreto - é a de reconhecer, sempre que possível, o concubinato como sociedade de fato, cujo patrimônio seja dividido e resolvido em conformidade com o direito das obrigações, estando nesse campo os demais efeitos civis resultantes.

Dentre tais efeitos civis, pode-se apontaroquesecunhou "remuneração" ou indenização à concubina "por serviços prestados”. Até então, era uma solução jurídica direcionada a respeitar a lei positiva civil que não previa a aplicação de regras do direito de família ao concubinato, por não se tratar de relação amorosa originária da família ou ao menos lícita e legítima. Contudo, atualmente, tais expressões são consideradas como "retrógradas", “ofensivas”, "machistas”, preferindose a adoção de uma terminologia mais neutra, como "esforço comum" e “contribuição".

No entanto, o caráter indenizatório deve permanecer quando a situação concreta for o concubinato, sendo indevido o mesmo tratamento à união estável, hoje equiparada à entidade familiar. $\mathrm{A}(\mathrm{O})$ concubina(o) que manteve relacionamento afetivo, por certo período de tempo, com outrem em estado de impedimento legal para contrair nova união lícita (casamento ou união estável), e que tenha formado com este patrimônio em comum, pode ter direito à pretensão indenizatória não só pelo período dedicado à relação (eventuais trabalhos e dações concedidos gratuitamente neste lapso temporal) como também a título de danos morais (vergonha e humilhação sofridos), se de boa-fé e alheia à situação de casado(a) do(a) concubino(a).

Dessa forma, a honra e dignidade perante a sociedade por parte do concubino(a) de boa-fé é devidamente resgatada e protegida pelo Direito, 
sem a correspondente necessidade de ferir a legislação positiva, numa postura equivocada de eventual reconhecimento de família ou de efeitos jurídicos aplicáveis somente ao casamento e à união estável. Dita orientação deve ser seguida inclusive por outros ramos do direito, como o previdenciário (proibição de reconhecimento de concubina como beneficiária, ainda que exista jurisprudência decidindo em sentido contrário), a fim de não resultar em contrariedades insanáveis em todo o sistema jurídico.

O direcionamento a ser seguido, pois, deve sempre ser o da legislação positiva, mormente o Código Civil (Brasil, 2003). As hipóteses de impedimentos para o casamento - que delimitam as situações de concubinato, como o adultério - estão arroladas no artigo 1.521. Dessa forma, percebe-se que todos os relacionamentos que se encaixem nas situações previstas no artigo 1.521 podem ser considerados como concubinato, pois assim estipulou o legislador, na finalidade de resguardar a família fundada no casamento, em primeiro lugar, e na união estável, equiparada a este.

Desse modo, permanece, indubitavelmente, no atual Código, a orientação de considerar o concubinato impuro como ilícito, cujos efeitos civis resolvem-se por meio do direito das obrigações, seguindo, como já dito, jurisprudência anterior já consolidada, bem como a tradição jurídica pátria (Brasil, 2003).

É necessário repetir que, apesar disso, outros efeitos civis foram reconhecidos pela jurisprudência, inclusive anteriores ao Código Civil atual. A primeira situação concreta reconhecida foi a separação de fato, que muitas vezes existe mesmo com o casal ainda residindo juntos. Depois, os efeitos patrimoniais foram ventilados em outros campos do direito civil, como o possessório, em que a composse da concubina foi reconhecida, mesmo em situação de adultério, devido à inexistência de direito de habitação ou propriedade da então esposa sobre o imóvel constituído individualmente pelo esposo, até porque, em verdade, o casal estava separado de fato há mais de dez anos (Malheiros; Malheiros Filho, 1995, p. 296).

Os casos concretos foram aumentando, e as diversidades de elementos fáticos e de circunstâncias particulares foram relativizando as prescrições legais de impedimento de constituição de nova família. In casu, as situações mais comuns eram de doações em dinheiro por parte do cônjuge adúltero à concubina; constituição de moradia e de convivência more uxório entre os concubinos; instituição de relações estáveis em concomitância ao casamento. Tais fatos contribuíram para a construção de critérios jurídicos 
pela jurisprudência para delimitar as situações, de modo a não interferir nem prejudicar a família legítima, então primordialmente protegida pelo Direito.

Malheiros e Malheiros Filho referem decisão judicial que reconheceu a validade de legado em testamento do homem casado à sua concubina, com a condição de que não prejudicasse a família legítima (acórdão $\mathrm{n}^{\circ}$ 585026743, da $5^{\text {a }}$ Câmara Cível do Tribunal de Justiça do Rio Grande do Sul, julgado em 04.02.1986), em claro reconhecimento de situação fática caracterizável como união estável, e não concubinato (Malheiros; Malheiros Filho, 1995, p. 297). Em outro aresto, anulou-se a ação reivindicatória do espólio contra a companheira do falecido, sob a alegação de que há distinção nítida entre concubinato e união estável, estendendo àquela os direitos inerentes à propriedade de bens móveis constituídos com o então companheiro na convivência permanente e duradoura (Malheiros; Malheiros Filho, 1995, p. 297).

O direcionamento jurisprudencial, parte de duas premissas: a existência de separação de fato (falência, pois, da comunhão plena de vida do casal) e a convivência estável e duradoura dos concubinos que, por essa circunstância, são reconhecidos, juridicamente, como companheiros, não incidindo os impedimentos legais previstos no Código nem a imputação de adultério. Dito critério tem por finalidade seguir a orientação finalística da lei civil de proteção à família formada pelo casamento, mas também de resguardo das situações não alheias ao direito que denotam uma quebra da situação conjugal não prevista pelo casal ao unir-se sob o mesmo teto.

Isso quer dizer que tanto a tradição jurídica pátria, quanto a lei civil (pelos Códigos de 1916 e 2002) elegem a família legítima como aquela formada pelo casamento, e colocam como principal ilícito civil a infidelidade conjugal (Malheiros; Malheiros Filho, 1995, p. 299), manifestada pelo adultério, passageiro ou repetitivo (este caracterizador do concubinato). Na ocorrência de concubinato, os efeitos civis são os previstos em lei resolvidos pelo direito das obrigações - e, nos casos de evidência de separação de fato, são equiparados ao casamento, resultando na consequente caracterização da união estável, que possui efeitos patrimoniais próprios.

\subsection{Posição do Concubinato entre as Entidades Familiares}

Em consonância com a lei civil, o concubinato sempre fora considerado situação contrária ao direito, cujo reconhecimento jurídico limitou-se aos efeitos patrimoniais oriundos de uma sociedade de fato. A evolução jurisprudencial, no entanto - com clara 
intenção de "acompanhar" ou "respaldar” costumes sociais contemporâneos, nem sempre conformes à lei e à justiça - passou a conferir um novo status ao concubinato impuro, qual seja, o de entidade familiar, mesmo na circunstância patente e irrefutável de adultério ou infidelidade.

Desde o antigo Código Civil de 1916, a hostilidade ao concubinato é notória. A possibilidade de ação reinvindicatória da mulher casada em relação aos bens comuns da sociedade conjugal transferidos ao marido adúltero (ou vice-versa); da anulação de doações em caso de adultério; da proibição de legado em testamento do cônjuge infiel para seu concubino (a); são determinações legais que, como visto, foram mantidas pelo atual Código, com vistas a proteger a família formada pelo casamento ou união estável.

A lei civil brasileira mantém-se na linha de severidade necessária com a infidelidade e seus efeitos (Malheiros; Malheiros Filho, 1995, p. 293). Contudo, situações como a do concubino (a) de boa-fé ou de verificação de uma separação de fato do casal (mesmo que mantendo uma certa visibilidade de casamento, mormente vivendo sob o mesmo teto) levaram a jurisprudência (principalmente a do Tribunal de Justiça do Rio Grande do Sul) a reconhecer efeitos civis não previstos no Código, contudo, sem elevar o concubinato à condição de família equiparada à união estável ou ao mesmo patamar que o casamento.

Malheiros e Malheiros Filho referem dois leading cases que iniciaram a relativização interpretativa da lei civil positiva: decisão que reconheceu a condição de seguro social à pecúlio instituído pelo cônjuge adúltero a concubina com quem conviveu por mais de vinte anos (acórdão $n^{\circ}$ 24.753, da $3^{\text {a }}$ Câmara Cível do Tribunal de Justiça do Rio Grande do Sul, julgado em 28.08.1975); e acórdão que definiu como legítima a indicação de concubina à condição de beneficiária de seguro de saúde, pelo cônjuge adúltero, devido ao rompimento da comunhão de vida com a então esposa e à consequente separação de fato do casal, situação que inviabiliza a caracterização do adultério (decisão no 29.953, do $2^{\circ}$ Grupo de Câmaras Cíveis do Tribunal de Justiça do Rio Grande do Sul, julgado em 15.12.1978) (Malheiros; Malheiros Filho, 1995, p. 295).

A partir dessa nova orientação, o Tribunal passou a considerar efeitos civis mais abrangentes ao concubinato impuro, desde que houvesse algum tipo de separação de fato ou rompimento da comunhão plena de vida entre o casal, e que a relação adulterina não fosse passageira ou transitória, assemelhando-se à união estável.

A proteção jurisprudencial dada ao concubinato puro (união estável), construção jurídica que culminou na disciplina dada ao instituto no 
Código atual, visou responder a uma demanda insurgente das próprias práticas sociais, fundadas sob a relativização total do casamento e da família constituída por este. Sobre esse fenômeno, acertadamente Athos Gusmão Carneiro asseverou:

O que constantemente vemos na prática é o espetáculo de cônjuges voluntariamente separados e cada qual com uma nova união irregular e que somente se recordam do vínculo do seu casamento para pedir a nulidade do legado feito pelo seu cônjuge a favor da concubina que o acompanhou por longos anos e lhe prestou assistência na sua enfermidade e velhice até a morte. O legado que o testador poderia legalmente fazer a qualquer pessoa não lhe seria lícito fazê-lo em benefício de sua concubina ainda que provassem assistência e serviço de natureza não sexual; tudo em homenagem a uma pessoa voluntariamente omissa e totalmente separada do seu marido e do seu casamento (Carneiro apud Marensi, 1990, p. 58).

O espetáculo que fala o eminente Ministro é, exatamente, a falência dos casamentos e, quem sabe, a inaptidão dos próprios casais de assumirem compromisso importante de fidelidade e, com base nesta mútua doação, buscar uma espécie de reconciliação ou entendimento. A ordem jurídica dá especial proteção ao casamento não por ser conservadora, ou "retrógrada”, mas sim por ser o instituto que mais exige de cada casal, muitas vezes renúncias e mudanças que já, de antes, um não estaria disposto a fazer pelo outro.

Dessa maneira, com razão lem-bra Carneiro (apud Marensi, 1990) que a prática corriqueira social são as separações de fato, com consequentes novos relacionamentos posteriores, estes caracterizadores do concubinato puro (união estável). E é certo que vários(as) esposos(as) que acabam por recordar do seu vínculo (ainda mantido "no papel”) estão desfeitos faticamente, quando afetam algum interesse jurídico particular ou quando visam a algum benefício post mortem (seja por herança, seja por pensão previdenciária ou de qualquer outro seguro). $\mathrm{O}$ erro, pois, não está na instituição casamento, mas nas decisões humanas, que devem ser, quando preciso, devidamente corrigidas pelo Direito, o qual é, em síntese, o instrumento que mantém a ordem das relações sociais.

Em outras palavras, não pode o Direito normatizar ou proteger toda e qualquer medida humana, pois assim estaria superveniente a um sociologismo que parte do pressuposto de que as decisões sociais são sempre corretas e devem seguir o seu devir "livremente". Se assim o fosse, períodos totalitários como o nazismo alemão não deveriam ser criticados, posto que, na época, o Direito fez exatamente o que vem procurando fazer hoje, dar respaldo jurídico a 
toda e qualquer decisão humana - a diferença é que, naquele período, a ditadura era estatal (governamental), e, hoje, a ditadura é social.

Essa nova visão do Direito - que ganhou força a partir do desenvolvimento de teorias contemporâneas da interpretação jurídica - permeia o círculo dos Tribunais e das decisões judiciais. Em matéria de direito de família isso é ainda mais latente. Os juízes passaram a ser a fonte primeira das regras familiares, diante do fenômeno da judicialização, quer dizer, do aumento de demandas sociais (até então resolvidas fora do Judiciário), ensejando um afastamento da aplicação principal do Direito, que é a exercida por meio da lei.

Nesse sentido, Rejane Filippi, ao comentar a união estável, chega a dizer que a tarefa de definição do instituto foi outorgada aos juízes, e não refere em nenhum momento à importância da lei escrita, a qual, primeiramente, a Constituição concede tal tarefa:

A toda evidência, não desejou o legislador constituinte definir a união estável, porque provavelmente cometeu ao Judiciário o mister de enriquecê-lo, ampliá-lo, e de todo o modo, em cada caso concreto, dizer onde está e onde não está a união estável (Filippi, 1991, p. 171).

Ora, não visa a lei engessar a atividade jurisprudencial, ou acabar com a atividade criadora do juiz. Por óbvio que a exata caracterização e verificação, no caso concreto, da efetiva existência de união estável é tarefa dada ao juiz. No entanto, a lei tem por finalidade dar os critérios mínimos de identificação, a fim de manter a ordem predicada pelo Direito e por todo o sistema normativo. Esse é o direcionamento dado pelo atual Código, que, ao dar parâmetros legais acerca de elementos essenciais do que seja a união estável e do que constitui o concubinato, confere segurança jurídica ao sistema jurídico e ao próprio Judiciário, na execução cotidiana da jurisdição.

Portanto, as decisões judiciais devem evoluir em consonância com a realidade social, mas, ao mesmo tempo, devem preservar a lei e atualizá-la. O que se verifica, porém, a partir da Constituição de 1988, e sob a vigência do Código Civil de 2002, é que a jurisprudência passou a orientar-se de forma mais agressiva, utilizando-se da interpretação jurídica para formar novo pensamento ou novas regras que, inclusive, beiram a posição contra legem. A nova hermenêutica contemporânea, amparada num critério princípio-lógicoconstitucional, transferiu ao julgador o poder de dar cabal visão não só à lei positiva, mas ao direito como um todo, alterando regras positivas claras e instituindo uma nova legislação alheia ao Código. 
Em matéria familiar, a jurisprudência pátria - principalmente a gaúcha - tem se direcionado nesse sentido. No caso do Tribunal de Justiça do Rio Grande do Sul, não raro se percebe orientações distintas, sobre o mesmo caso concreto, por Câmaras Cíveis diferentes, resultando numa situação jurídica absurda da chamada “sorte da distribuição”, isto é, terá "sorte" o processo distribuído para a Câmara " $x$ " que tem tomado decisões favoráveis ao caso particular, e terá "azar" aquele que "caíra” na Câmara “y”, de orientação contrária.

Mais do que isso: em matéria de direito de família - cujos fatos são extremamente sensíveis, fundamentais, tratando-se de uma família, de pessoas, de crianças, de patrimônios de uma vida inteira essa relativização desmedida causa prejuízos irremediáveis às vidas que estão por detrás do processo judicial, bem como ao sistema jurídico como um todo, pensado pela sociedade por meio de seus representantes políticos que formulam a lei positiva. Tamanha falta de critério ocasiona a transformação do Código Civil num livro de cabeceira, o qual serve apenas de "consulta” para fundamentar uma decisão ou interpretação já tomada pelo julgador antes de estudar o que diz a lei.

Dita postura fica manifesta quando o assunto é o concubinato. Decisões recentes do Tribunal de Justiça do Rio Grande do Sul reconheceram ao concubinato (mesmo com a clara evidência e prova de adultério e infidelidade) o status de entidade familiar, mesmo inexistindo qualquer persecução de verificação de boa-fé por parte da concubina(o), contrariando dispositivos da lei civil (que, inclusive, prevê a possibilidade de verificação de culpa na separação se verificado ao adultério) e da própria jurisprudência anterior já consolidada, a qual sempre procurou adaptar a lei ao devir social, e não alterá-la em conformidade com esse devir.

Como dito, em nenhum momento os Tribunais reconheceram o concubinato como família, mas tão somente admitiram a existência de outros efeitos civis não previstos pela lei civil. A nova jurisprudência, contudo, diz o que é família, englobando nesse conceito "vazio" quaisquer relações afetivas sociais existentes, incentivando, inclusive, a formação de mais de uma família ou de famílias paralelas, claramente instituindo, contra legem e contra a consuetudo, a poligamia.

É o que se verifica na decisão transcrita a seguir:

[...] o fato de o varão ter mantido seu casamento em concomitância com o relacionamento havido com a apelante, não seria, por si só, impedimento para o reconhecimento da união estável. Não é de hoje que essa Oitava Câmara tem se manifestado favoravelmente ao reconhecimento da união estável concomitante ao casamento ou concomitante a outra união estável. 
[...] Então, o argumento de que a segunda união seria de natureza concubinária e que, por isso, não seria lícito o reconhecimento da união estável paralela ao casamento, “data venia”, penso que já foi superado por um significativo número de julgamentos no âmbito deste órgão fracionário $^{4}$ (Rio Grande do Sul, 2008c, p. 6).

Note-se que os critérios até então considerados pela jurisprudência - a existência de separação de fato e a diferenciação necessária entre a união estável eo concubinato-parece ter sido afastada pelo novo direcionamento, qual seja, de reconhecer tantas e quaisquer relações paralelas que alguém possa vir constituir, desde que sejam “duradouras”, “públicas”, e com o "intuito de constituir família”. A lei civil, quando fala da fidelidade, da reciprocidade, do auxílio mútuo entre os cônjuges e companheiros, está completamente afastada pelo direcionamento jurisprudencial dantes referido, o qual admite que uma mesma pessoa possa comprometer-se a ter fidelidade perante duas ou mais outras com as quais venha constituir as "suas famílias".

Em sentido contrário, no entanto, orientam-se as decisões expostas abai- xo, que, por sua clareza e coerência, dispensam quaisquer comentários:

O presente caso traduz aquilo que Gischkow chamou de monetarização do afeto, ou seja, a parte entregase em uma relação paralela ao casamento, uma verdadeira 'relação aberta' e, frustrada, pretende compensar-se monetariamente. [...] Admite o autor expressamente que o relacionamento havido entre Apelante e Apelada preenche os requisitos de um concubinato impuro, como se a lei civil reconhecesse e protegesse duplicidade de relaç̃es conjugais no Direito de Família. À evidência, isso tornaria 'um nada' a instituição oficial do casamento, porque qualquer relacionamento amoroso, mesmo com prostitutas, poderia ser indenizável como se tratássemos de relações de família. Podemos seguir adiante nas 'interpretações', mas não confundir institutos jurídicos [...] Sabemos que o casamento e a união estável têm amparo na lei e na Constituição Federal, sendo que o legislador civil distinguiu precisamente o concubinato. [...] Para o concubinato adulterino persistem algumas regras coibitórias de direitos, no plano patrimonial, em resguardo aos direitos de família constituída pelo casamento [...] Com o advento da Constituição de 1988, o relacionamento homemmulher com partilha de bens dá-se

4 Trecho de voto do Des. Rui Portanova nos autos da Apelação Cível nº 70024608507, $8^{a}$ Câmara Cível do Tribunal de Justiça do RS, Rel. Des. Alzir Felippe Schmitz, julgado em 9 out. 2008. 
no casamento e na união estável, mas não no concubinato, não na relação aberta ou na sociedade de fato. Eventuais considerações econômicas devem ser solvidas no plano obrigacional, não no familial. (...) o autor é casado, com casamento em plena validade e confessada quebra dos deveres matrimoniais. Assim, o reconhecimento de sua pretensão seria agressão à instituição legal do casamento. [...] O casamento, seja por contrato, seja como instituição, impõe deveres legais e responsabilidade ética não podendo descambar para o reconhecimento de relações paralelas e à margem da lei $^{5}$ (Rio Grande do Sul, 2008b, p. 3-5, grifamos).

Tendo havido inequivocamente uma relação amorosa entre a autora e o demandado, típica de um mero concubinato, evidentemente mostra-se descabido o pedido de indenização, que carece de amparo jurídico, visto que não se pode dar mais à concubina do que teria se casada fosse, valendo lembrar que não é a esposa aquinhoada com contraprestação por serviços domésticos prestados à família e ao marido. [...] Por oportuno, vale observar que a indenização por serviços domésticos prestados era admitida na esfera da Justiça
Estadual e no âmbito do Direito de Família como um artifício para se evitar injustiças contra a mulher que se dedicava a uma união livre, mas com caráter 'more uxorio', quando não havia as leis protetivas dessa modalidade de família, que veio a ser concebida e legalizada com o nome de união estável. [...] Trata-se aqui de uma relação eminentemente amorosa, não se cogitando de um contrato de trabalho, nem prestação civil de trabalho na modalidade locação de serviços..., nem se cuida de uma entidade familiar. Afinal, o réu era casado e convivia com sua família. E esse fato era conhecido da autora, que fora empregada da família. [...] houve entre os litigantes o estabelecimento de um mero vínculo afetivo e sexual, relacionamento este que não apresenta qualquer conteúdo econômico, nem se confunde com uma entidade familiar ${ }^{6}$ (Rio Grande do Sul, 2008a, p. 5-7, grifamos).

As relações familiares sempre ensejam tais discussões e serão constantemente o foco das principais mudanças normativas e de interpretações jurídicas. Talvez por envolverem não só o amor ou “afeto" - palavra que sumariza demais o profundo sentimento que une

5 Trecho do voto do Des. Alzir Felippe Schmitz, nos autos da Apelação Cível no 70023890601, $8^{\text {a }}$ Câmara Cível do Tribunal de Justiça do RS, Rel. Des. Alzir Felippe Schmitz, julgado em 25 set. 2008.

6 Trecho do voto do Des. Sérgio F. Vasconcellos Chaves, nos autos da Apelação Cível $n^{0}$ 70023332794, $7^{\text {a }}$ Câmara Cível do Tribunal de Justiça do RS, Rel. Des. Sérgio Fernando de Vasconcellos Chaves, julgado em 24 set. 2008. 
pessoas sob a mesma família, pois ele não explica, em sua etimologia, as renúncias e sacrifícios que uns fazem pelos outros (pais, filhos, irmãos, netos), nem os egoísmos e ódios que possam surgir, mas só o amor e a falta de amor - mas também elementos culturais, religiosos, morais, até biológicos que inafastavelmente fazem parte das relações humanas (porque são próprios do ser humano).

Ousada, nesse sentido, é a lição de Pontes de Miranda:

Quem não é cônjuge não se torna cônjuge pelo fato de ser tratado como tal. Ser criado como filho não é ser filho. Ter bens em comum com o cônjuge não é estar sob o regime matrimonial da comunhão. Podese ser membro da família sem se viver na mesma casa e, até, sem se conhecerem os próprios irmãos. As tentativas de dilatação do círculo família fracassam sempre. Cada vez o círculo família diminui, nas relações da vida (Pontes de Miranda, 2001, p. 80).

\section{CONCLUSÃO}

Advogar em favor da tradição jurídica e da segurança de seus institutos, para muitos, soa um discurso retrógrado ou, por vezes, discriminatório. O direito de ser diferente parece que não é aplicável àqueles que pugnam por um respeito ao Direito e à sua história, à lei e aos seus critérios, e, no direito de família, a instituição do casamento. Tais defensores, atualmente, são os diferentes que, por ironia, não podem invocar o seu direito de assim ser diferente, e de assim pensar.

A relativização do Direito, e de seus métodos de interpretação levam, pois, a uma própria ditadura desse fenômeno. É válido reconhecer juridicamente todo e qualquer fato social; mas não é igualmente válido dar guarida a institutos já previstos normativamente e dogmaticamente, os quais talvez não encontrem mais adoção filial por parte da sociedade humana.

Essa variabilidade jurídica - que formam os chamados "conceitos vazios" do Direito, os quais podem ser preenchidos por qualquer conteúdo e quaisquer ideologias - atinge fundamentalmente o Direito de Família. Conceitos como casamento, união estável e concubinato perdem seus critérios e referências para tornarem-se apenas parâmetros gramaticais de situações de fato muitas vezes transitórias e constantemente mutáveis.

Entender os institutos jurídicos em consonância com sua tradição e história não causa uma petrificação das situações fáticas, mas sim consolidam conteúdos que, atualizando-se com a realidade, em seu devir, auxiliam o Direito a manter e estabelecer a ordem - que é sua finalidade principal. E a ordem não se separa da constância; a constância está unida à perenidade; e essas são vivas no meio social por 
meio da conhecida relação entre fato, valor e norma.

Talvez no âmbito do Direito de Família o aspecto que tenha sofrido maiores dilacerações seja o valor. Não se compreende por valor apenas as orientações ideológicas ou religiosas, mas também as culturais e tradicionais. Igualmente, não se entende por cultura apenas aquela que se modifica com o tempo, mas da mesma forma os costumes sociais que sempre permanecem, e não tão cedo desaparecerão, pois fazem parte do próprio ser humano.

Os institutos jurídicos familiares sempre serão protegidos pelo Direito, pois traduzem relações humanas que sempre existirão, principalmente o casamento. O casamento é tratado na lei civil como base para formação da família, pois traz ínsito na sua constituição a promessa e compromisso de direitos, deveres, mútua colaboração, doação, comunhão plena de vida e, principalmente, amor. O casal que busca casar-se deve ter plena noção do valor desse compromisso; tanto é assim que o crescimento, hoje, da opção por união estável deve-se exatamente ao ambiente de insegurança na sociedade contemporânea, em que já não se con- fia mais no outro ou se tem esperanças de que ele irá cumprir as promessas exigidas pelo instituto matrimonial. Para tanto, propôs lei civil, prudentemente, a conversibilidade desta união em casamento, dando a oportunidade ao casal de assumirem esse compromisso mútuo e a responsabilidade de um perante o outro talvez pelo resto de suas vidas.

O concubinato, nesse sentido, não pode ser considerado família, ou entidade familiar, pois é fruto dessa quebra de confiança, de fidelidade, de comunhão plena de vida entre o casal. Pode significar, psicologicamente, uma fuga desse compromisso, ou uma falta de integridade em admitir que sua relação matrimonial passa por problemas e dificuldades. O que não pode - pois seria uma afronta ao valor jurídico presente no instituto do casamento - é ser considerado como uma relação amorosa juridicamente válida, paralela ao casamento ou união estável, pois estar-se-ia desrespeitando não só a lei civil (que também é querida pela sociedade) mas também as próprias pessoas envolvidas na situação de fato, incitando-as a permanecerem no erro ou, talvez, na inconstância de suas vidas. 


\section{REFERÊNCIAS}

AZEVEDO, Álvaro Villaça. Do concubinato ao casamento de fato. 2 ed. Belém: CEJUP, 1987.

BEVILÁQUA, Clóvis [1859-1944]. Direito da família. 2. ed. Recife: Ramiro e Costa, 1905.

BRASIL. Novo código civil brasileiro: lei 10.406, de 10 de janeiro de 2002: estudo comparativo com o código civil de 1916, Constituição Federal, legislação codificada e extravagante. 3. ed. rev. e ampl. São Paulo: Revista dos Tribunais, 2003. $831 \mathrm{p}$.

COULANGES, Numa Denis Fustel de [1830-1889]. A cidade antiga. São Paulo: Martins Fontes, 1998.

FILIPPI, Rejane Brasil. O concubinato após a nova Constituição Federal. Revista da AJURIS, Porto Alegre, v. 18, n.51, p. 167-173, mar. 1991. MALHEIROS, Fernando; MALHEIROS FILHO, Fernando. Aspectos do concubinato adulterino. Revista da AJURIS, Porto Alegre, v. 22, n. 64, p. 293-301, jul. 1995.

MARENSI, Voltaire. Concubinato: legado e seguro de vida. Revista da AJURIS, Porto Alegre, v. 17, n. 50, p. 57-61, nov. 1990.

NORONHA, Carlos Silveira. Fundamentos e evolução histórica da família na ordem jurídica. Direito e Justiça: Revista da Faculdade de Direito da PUCRS, Porto Alegre, v. 21, n. 20, p. 51-76, 1999.
PETIT, Eugène Henri Joseph [18501931]. Tratado elemental de derecho romano. Buenos Aires: Albatros, 1970.

PONTES DE MIRANDA, Francisco Cavalcanti [1892-1979]. Tratado de direito de família. Atualizado por Vilson Rodrigues Alves. Campinas: Bookseller, 2001. v. 1. REALE, Miguel [1910-2006]. Cônjuges e companheiros. [São Paulo], 2004. Disponível em: <http:// www.miguelreale.com.br/artigos/ conjcomp.htm>. Acesso em: 20 dez. 2008.

RIO GRANDE DO SUL. Tribunal de Justiça. $7^{\text {a }}$ Câmara Cível. Acórdão na Apelação Cível $n^{\circ}$ 70023332794. Rel. Des. Sérgio Fernando de Vasconcellos Chaves, julgado em 24 set. 2008. Porto Alegre, 2008a.

RIO GRANDE DO SUL. Tribunal de Justiça. $8^{\text {a }}$ Câmara Cível. Acórdão na Apelação Cível $n^{\circ}$ 70023890601. Rel. Des. Alzir Felippe Schmitz, julgado em 25 set. 2008. Porto Alegre, 2008b.

RIO GRANDE DO SUL. Tribunal de Justiça. $8^{\mathrm{a}}$ Câmara Cível. Acórdão na Apelação Cível $n^{\circ}$ 70024608507. Rel. Des. Alzir Felippe Schmitz, julgado em 9 out. 2008. Porto Alegre, 2008c.

RIZZARDO, Arnaldo. Casamento e concubinato: efeitos patrimoniais. Rio de Janeiro: Aide, 1985. 